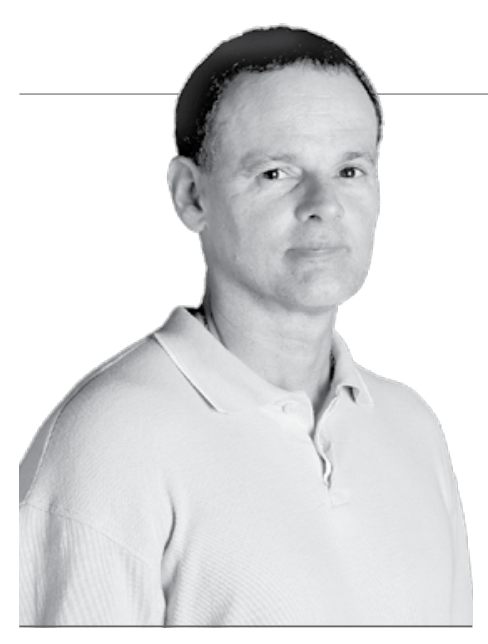

\title{
Representações da figura feminina no imaginário poético de fins do século XIX
} Representations of the female figure in the poetic imagination
of late 19th century

\section{Representaciones de la figura femenina en la imaginación poética a fines del siglo XIX}

O presente artigo procura, a partir de uma revisão de alguns preconceitos (GADAMER) da crítica e da historiografia literária brasileiras sobre o parnasianismo e o simbolismo, reler na produção poética parnasiana as diferentes formas de representar a figura feminina, destacando algumas manifestações da mulher fatal: a mulher que vem do abismo das águas, a estátua, a esfinge, a mulher sonhada e a sereia. Busca, por outro lado, demonstrar que certos elementos do imaginário poético parnasiano, como a sereia, lograram penetrar o imaginário da cultura popular, aparecendo em letras de canções da MPB e de sambas-enredo, através da simbiose com as figuras da Iemanjá (de origem africana) e da Iara (de origem indígena).
The present article looks for, from a revision of some preconceptions (GA$D A M E R$ ) of critical and the literary historiography Brazilian on the Parnassian and the symbolism, to reread in the Parnassian poetical production the different forms to represent the feminine figure, detaching some manifestations of the fatal woman: the woman who come of the abyss of waters, the statue, the sphinx the dreamed woman and the siren. Search, on the other hand, to demonstrate that certain elements of imaginary the Parnassian poetical as the 'siren', had cheated to penetrate the imaginary one of the popular culture, appearing in letters of songs of the MPB and samba-plot, through the symbiosis with the figures of the 'Iemanja' (of African origin) and of the 'Iara' (of aboriginal origin).
El actual artículo busca, de una revisión de algunas preconcepciones (GA$D A M E R$ ) de crítico y del del historiografia brasileña literarias en el parnasianismoy el simbolismo para releer en la producción poética del parnasiana las diversas formas para representar la figura femenina, separando algunas manifestaciones del la mujer seducer la mujer que viene del abismo de las aguas, de la estatua, del esinge, de la mujer soñada y del sereia. Busque, por otra parte, para demostrar que ciertos elementos de imaginario el parnasiano poético, como el sereia, habian engañado para penetrar el imaginario de la cultura popular, apareciendo en letras de las canciones del MPB y samba, con la simbiosis con los figuras del Iemanjá (del origen africano) y del Iara (del origen aborigen).
Palavras-chave: poesia, parnasianismo, representações da figura feminina, mulher fatal, sereia.

\section{Autor:}

\section{Prof. Dr. Claudius Bezerra Gomes Waddington}

Bacharel, Licenciatura Plena, Mestre e Doutor em Letras pela UFRJ; professor de Literatura Brasileira, Teoria da Literatura e Literatura Comparada dos cursos de graduação e pós-graduação em Letras da Estácio.

E-mail: claudiuswaddington@ig.com.br

\section{O mar, misterioso mar \\ Que vem do horizonte \\ É o reino das sereias \\ Lendário e fascinante \\ Olha o canto da sereia}

$$
\text { (Dinoel-Vicente Matos - Veloso) }
$$

Cristalizou-se na historiografia da literatura brasileira a idéia de que o parnasianismo distinguir-se-ia do romantismo essencialmente pelo aspecto formal. A sentença modernista, que reduziu o parnaso a uma "máquina de fazer versos", insistindo na gratuidade e na repetição de fórmulas desgastadas, contribuiu decisivamente para encobrir o que Péricles Eugênio da Silva Ramos denominou “a renovação parnasiana na poesia”. Escorados em livros de história da literatura brasileira como a História concisa da Literatura Brasileira de Alfredo Bosi, os manuais didáticos repetem, à saciedade, os slogans antiparnasianos, inscrevendo no "saber compartilhado", no "arquivo", na "memória" ou na "enciclopédia" dos leitores em formação o preconceito do parnasianismo enquanto modismo de importação, estetismo irracional, alheado da realidade histórica e social do Brasil de fins do século XIX. A distorção perceptiva agrava-se no que diz respeito ao simbolismo, via de regra visto como a radicalização dos aspectos negativos do parnaso, o grau extremo de um processo de afastamento da realidade e obsessão patológica pela forma. Somos herdeiros, e alguns de nós cúmplices, desta imagem distorcida de ambos os movimentos, construída e reproduzida nos livros de história e nos manuais didáticos de literatura brasileira. De tal forma estas distorções crítico-historiográficas encontram-se entranhadas em nosso imaginário leitor e são inculcadas aos leitores em formação, que são percebidas como naturais, mas, na verdade, foram naturalizadas. Por conseguinte, qualquer opinião divergente, qualquer tentativa de revisão, é imediatamente desacreditada como improcedente ou ingênua. Para perceber que o parnasianismo e o simbolismo não se resumiram a esta contrafação da crítica e da historiografia literárias, é necessário 
esforçarmo-nos por desentranhá-los desta perspectiva reducionista, para enxergar as múltiplas rupturas por eles empreendidas no ideário poético romântico e realista. Mas para tanto, é mister ler efetivamente a poesia parnasiana e simbolista - o que hoje se faz cada vez menos - , não substituindo a leitura dos textos literários pelo que disse e diz a crítica e a historiografia literária, dar-lhes uma segunda chance, o direito de defesa da condenação sumária e sem apelação de que foram alvo.

Os movimentos parnasiano e simbolista foram e permanecem sendo analisados, avaliados e condenados pela crítica e pela historiografia literárias a partir de pontos de vista e em perspectivas estranhos às propostas específicas e próprias de cada um dos movimentos. O parnasianismo e o simbolismo são explícita ou implicitamente, e de forma mais ou menos consciente, confrontados ao romantismo, ao realismo e ao modernismo. Mesmo hoje, parnasianismo e simbolismo continuam sendo investigados, não pelos seus méritos intrínsecos, pela realização estética que lograram alcançar ou pelo projeto estético que os animou, mas contrapondo-os ao ideário estético, ético e político romântico, à arte comprometida com a análise e a crítica da sociedade do realismo e ao programa de experimentação destrutiva da tradição defendido pelas vanguardas e endossado pelo modernismo. Do romantismo herdou a crítica e a historiografia literárias certos "preconceitos": da arte criada pelo gênio como gesto de liberdade, da arte como expressão da subjetividade, comprometida com o outro por um ideal de fraternidade, pressupondo a igualdade na comunidade leitora e imbuída de um caráter missionário, porque partidária da arte engajada. Do realismo herdou o compromisso com uma representação que desmascara a sociedade, desnuda o real, apelando para a razão e a reflexão do leitor. Das vanguardas e da fase heróica do modernismo herdaram o pressuposto de que a arte é, antes de mais nada, ruptura, inovação, produção do novo, do inesperado, do inusitado, produto de uma experiência pessoal que enfrenta e desafia as expectativas do público leitor, desarruma o sistema literário e invalida ou demole a tradição literária. Acresce e aprofunda a incompreensão crítico-historiográfica do parnasianismo e do simbolismo a idéia - cara à nossa segunda geração modernista, a de 1930 - de uma arte obrigatoriamente jungida à representação da realidade histórica, social, econômica e política, de denúncia da opressão do meio social e natural sobre o homem, movida por uma concepção ilustrada ou iluminada de arte dedicada à crítica, a fim de torná-la útil e necessária à consciência da sociedade. Especificamente com relação ao modernismo, podemos distinguir dois mecanismos atuando neste processo de deformação histórico-crítica do parnasianismo: o esforço de auto-afirmação feito pelos próprios modernistas a expensas do parnasianismo e a tradição crítico-historiográfica detratora derivada deste empenho dos modernistas em negar o parnasianismo, que consagrou e naturalizou a postura anti-parnasiana na crítica e na historiografia literárias brasileiras.

Este "entulhamento" da crítica e da historiografia literárias por preconceitos e pressupostos de diferentes momentos da evolução literária nacional, estranhos aos programas estéticos do parnasianismo e do simbolismo, não é, contudo, imediatamente perceptível, sobretudo para uma visão viciada em julgar projetos e programas estéticos diversos a partir de um elenco fechado e invariável de princípios, que são tomados como de validade e aplicação universal e atemporal, indiscriminadamente. Este processo de deformação só se torna perceptível a analisável quando a reflexão crítica e historiográfica parte da crítica dos pressupostos teórico-metodológicos preconizada pela hermenêutica de Hans-Georg Gadamer, destacadamente, mas não só, em
Verdade e Método, para a qual conflui a hermenêutica literária desenvolvida por um dos pioneiros da Estética da Recepção, Hans Robert Jauss, conhecido por insistir na reconstrução da história literária a partir da crítica de seus fundamentos teóricos e metodológicos.

Partindo do ensino de Gadamer, percebemos que são pressupostos e "preconceitos" não auto-realizados e não explicitados pela crítica e pela historiografia literárias que levaram à depreciação e à condenação do parnasianismo e do simbolismo. Esta tradição crítica e historiográfica debate-se dentro da incompreensão do que investiga, pois considera natural cobrar originalidade, comprometimento social e ruptura com a tradição, de dois movimentos que não os incluíram em seus programas e nem em seus ideários. Os pressupostos e "preconceitos" que moveram parnasianismo e simbolismo não devem ser mecanicamente procurados no romantismo, no realismo e no modernismo. Uma crítica e uma historiografia literárias mais lúcidas e perspicazes os demandariam - no caso do parnasianismo - , ao horizonte de expectativas e à forma como as relações entre autor, texto, comunidades-leitoras, intertexto e contexto foram pensadas e funcionaram dentro dos padrões e da época do classicismo e/ou do neoclassicismo, pois é o princípio clássico da imitação que rege o parnasianismo. Da imitatio da antiguidade clássica, como imitação da natureza, e da imitatio renascentista, como imitação dos modelos, derivam, em parte, a tendência descritiva, que se desenvolverá na poesia plástica e na poesia filosófica (enquanto pintura da natureza humana), e a tendência à citação da tradição e a reverenciar os autores modelares. Pretender que a imitação se reduz ao retrato do real e pretender que a reverência aos mestres não passa de cópia mal disfarçada é ignorar, simultaneamente, os protocolos de escrita que norteavam a produção do texto literário e os protocolos de leitura que dirigiam sua recepção no classicismo e no neoclassicismo, os quais dispunham um espaço de reiteração de autores, textos, personagens e enredos reconhecidos como modelos. A fonte de inspiração maior passa a ser, nos momentos da evolução estética ocidental em que predomina ou vigora o classicismo ou o neoclassicismo, a tradição. E a sua imitação não é então concebida como falta, como deficiência ou incapacidade, até porque via de regra não se trata de mera cópia, mas, geralmente, nos bons momentos dos bons autores do parnasianismo, de imitação criativa. A imitação criativa fecunda a descrição da natureza das coisas e do homem com a evocação da memória, da enciclopédia, que o autor parnasiano pretende compartilhar com seu leitor. E fecunda, igualmente, o texto e/ ou o autor citados, parafraseados, traduzidos ou reverenciados com a sua notação pessoal, sua singularidade, e com a diferença que implica a reinscrição do autor, do texto ou de seu fragmento em outro e novo horizonte de expectativa, outra e nova situação hermenêutica, isto é, novas e diferentes condições de leitura, interpretação e compreensão, outro e novo sistema literário, outros e novos protocolos de escrita e de leitura, outro e novo contexto, outra e nova época.

O parnasianismo afasta-se do projeto estético e poético do romantismo não apenas no aspecto formal, mas igualmente pela constituição de um elenco temático próprio e, em alguns casos, pela reintegração de temas já conhecidos, mas que ganham no novo enquadre outras significações ou que tem o campo do sentido ampliado ou pluralizado em isotopias inéditas ou imprevistas. Não houve sempre, contudo, uma passagem linear do romantismo para o parnasianismo, permanecendo até hoje árdua a tarefa de estabelecer o que sucede ao romantismo. Houve na verdade mais de um caminho para os poetas insatisfeitos de 
meados do século XIX tornarem-se pós-românticos. Podemos, didaticamente, distinguir três situações: 1) os que evoluem do romantismo para o parnasianismo, como Luis Guimarães Júnior e Alberto de Oliveira; 2) os que fazendo o percurso para o parnasianismo, passam pela transição realista ou socialista, tendo aderido à Idéia Nova, como Teófilo Dias e Raimundo Correia; e 3) os que estreando na época do parnasianismo consagrado, não se conformam com a ortodoxia do modelo francês e transpõem seus limites, como Olavo Bilac. Altera-se a relação parnasianismo/romantismo de cada uma destas situações para a outra, não sendo lícito falar em uniformidade. Há ainda que se considerar a questão da transição. A década de 1860 na Europa já é a década da publicação da antologia O Parnaso Contemporâneo, em que estréiam ou ganham notoriedade os principais nomes do movimento, mas é igualmente a década da poesia social e da literatura engajada no Brasil, cujo modelo era Victor Hugo. Victor Hugo que arrebatava a Europa nesta década com os romances Os miseráveis de 1862, Trabalhadores do mar de 1866 e O homem que ri de 1869 . No Brasil, os anos sessenta do século XIX assistem ao triunfo do romance alencariano na prosa e da poesia social de Fagundes Varela e Castro Alves, somente os anos setenta apresentam já elementos que escapam ao enquadre romântico, apontando para a sua ultrapassagem; não obstante a linha que separa a poesia social romântica de inspiração hugoana dos anos sessenta da poesia socialista dos anos setenta não seja assim tão intransponível.

O parnasianismo distanciar-se-ia do romantismo em vários aspectos, tanto de caráter formal quanto temático. $\mathrm{O}$ "culto da forma", como o denomina Alberto de Oliveira, seria consagrado na década de oitenta do século XIX e definiu-se, simultaneamente, como uma negação do projeto idealista, revolucionário e libertário do romantismo e como resgate da poética clássica, como o prova um dos mais bem realizados sonetos de Via Láctea de Bilac, o XXV, dedicado a Bocage: "Tu, que no pego impuro das orgias / Mergulhavas ansioso e descontente, / E, quando à tona vinhas de repente, / Cheias as mãos de pérolas trazias;". O princípio da "arte pela arte", não implicando apenas um estetismo vazio e alienado, insistia acima de tudo sobre a autonomia - que evoluiria para a defesa intransigente de uma independência absoluta - e a superioridade da arte sobre os aspectos morais, sociais e políticos da existência. Em poetas como Baudelaire a tese da superioridade da arte sobre a moral e a religião daria lugar a um verdadeiro escândalo, que o arrastaria ao processo e à condenação de As Flores do Mal pela justiça, esta já suspensa, e à incompreensão de sua obra, esta ainda em vigor. De um lado, desdobrou-se o princípio da "arte pela arte" na impassibilidade ou impessoalidade do discurso parnasiano - em oposição ao discurso fortemente subjetivo e expressivo do romantismo - , que o inclinaria para um tratamento mais objetivo da realidade. Por outro lado, o mesmo princípio apontava para o desengajamento da arte, simultaneamente em confronto com o projeto romântico e o da poesia socialista. O descritivismo parnasiano não se confundia, contudo, com o inventário ou arrolamento da poesia realista, uma vez que a descrição parnasiana não se esgotava na notação crua do mundo empírico, mas fecundava-o com o imaginário exótico.

A temática exótica parnasiana distinguia-se da romântica por substituir a imaginação ou fantasia pela evocação da "enciclopédia" do leitor, apelando, portanto, para a capacidade do leitor de co-laborar com o texto, processando as referências eruditas nele indicadas ou criptografadas. A temática exótica parnasiana apresentava quatro vertentes: 1) a história e a cultura da antiguidade greco-latina, 2) a tradição judaico-cristã primitiva, 3) o oriente mítico e 4) os vícios e as drogas. Byron e o Hugo de As Orientais de 1829 foram os precursores da onda helenizante no romantismo, a qual triunfaria em Os Poemas Antigos, escritos entre 1852-1874, por Leconte de Lisle, aliás, tradutor da Ilíada e da Odisséia de Homero. A voga orientalista por sua fez, insuflada nos meios intelectuais franceses a partir da década de 1840 por Burnouf, assumiria suas vestes propriamente parnasianas com os Poemas Hindus de Leconte de Lisle e seria consagrada nos Poemas Bárbaros de 1862-1878 do mesmo autor. Quando Heredia publicou os seus Os Troféus em 1893 a temática antiga e orientalista já estava consolidada no movimento. Das quatro vertentes duas conquistaram o gosto dos nossos poetas: os personagens tanto históricos, quanto literários e míticos da antiguidade greco-latina e judaico-cristã povoariam Panóplias, Sarças de Fogo, Alma Inquieta, As Viagens e alcançariam Tarde de Bilac. Entretanto, as outras duas vertentes da temática exótica, a do orientalismo e a dos vícios e drogas, esta última crucial para a afirmação da modernidade de As Flores do Mal de Baudelaire, não fincariam raízes profundas no nosso parnasianismo.

Um dos aspectos em que o parnasianismo distanciar-se-ia do romantismo seria o tratamento dado à representação da figura feminina. O romantismo tendeu a estereotipar a figura feminina, a partir da cisão entre uma face conforme às convenções idealizantes e espiritualizantes, que finca suas raízes em uma tradição literária de idealização da figura feminina e de sublimação do desejo que remonta a Dante e Petrarca, e ao imperativo da sublimação do desejo na sociedade patriarcal do século XIX - é a ela que corresponde a bela entressonhada no soneto "Pálida, à luz da lâmpada sombria" ou a etérea "Teresa"ou a beleza angelical de "Pálida imagem", todos de Álvares de Azevedo - , e uma outra face depreciada, costumeiramente associada à mulher do povo ou à mulher decaída - é a ela que corresponde a lavadeira de "É ela! é ela! é ela! É ela!" do mesmo Álvares de Azevedo. O antológico poema de Casemiro de Abreu "Amor e medo" apresenta, de forma emblemática, a motivação psicológica subjacente a esta percepção cindida da figura feminina: a mulher que se "ama" (entendendo aí o sentimento separado do desejo sexual) não se pode "conhecer" (no sentido bíblico), o "conhecimento" corresponde a queda moral. Ora, o parnasianismo desafiará essa convenção romântica e renderá culto à imagem da mulher fatal, atraente, irresistível, sensual, dominadora, porém, contraditória. A contraditoriedade da figura feminina, a convivência do bem e do mal, do divino e do demoníaco, da beleza mais sublime com a voracidade do desejo carnal, no mesmo ser - realizada de forma modelar no antológico "Hino à Beleza" de Baudelaire — , seria privilegiada pelo parnasianismo europeu e brasileiro, correspondendo a uma renovação temática no imaginário poético do ocidente. Essa renovação teve em seu epicentro As Flores do Mal, livro deflagrador da lírica moderna. Neste livro, revolucionário sob vários aspectos, sobreleva o tratamento anti-convencional dado por Baudelaire à sua exótica galeria de personagens femininas, na qual, ao lado da figura idealizada dos poemas inspirados ou ligados à Madame Apollonie Sabatier, encontramos aqueles de forte, porém discreto e elegante erotismo, referidos a Jeanne Duval e a Marie Daubrun, a que se somam poemas onde a sensualidade se faz acompanhar de notações grotescas, irônicas, sarcásticas, por vezes até góticas, nas figuras das transeuntes, mendigas, prostitutas, vampiras, esqueletos e estátuas disformes.

Para falar dessa mulher fatal, plena de contradições, o 
parnasianismo brasileiro privilegiou algumas representações da figura feminina: a beleza venusiana - a mulher que vem do abismo e que atrai para ele, tão sensualmente irresistível quanto inacessível - ; o ideal marmóreo - inconspurcável, etéreo, celestial, frio; a mulher que surge como uma aparição em sonho - sublime, porém quase imaterial — ; e a sereia que encanta, fascina e mata. Vênus ou Afrodite, desde sempre identificada com a beleza de arrasador apelo sexual, não constitui uma inovação parnasiana; é antes um resgate da cultura clássica, constantemente evocada para designar a mulher no auge da beleza física e do poder de sedução, mas que não se pode possuir. Encontramo-la em "Aparição nas águas" do livro de estréia de Alberto de Oliveira, Canções Românticas de 1878.

Que aparição de luz! Em breve, em breve Vais na água flutuar!

Ah! Que as ondas, cruel, não sejam lábios, E que eu não seja o mar!

É enquanto aparição que surge e, intocada, desaparece ("Num relâmpago foges") que Vênus é aí representada, posta a salvo do ímpeto erótico incorrespondido.

Quem não sentira n’alma estes arrancos,

Todo o ferver do interno cataclismo,

Ao ver-te nua, ao ver-te os seios brancos,

As formas de Diana,

Banhadas de uma luz prometeana,

Ó sideral aparição do Abismo!

O clima não difere e o desfecho não é outro em "Afrodite", do livro que marca a adesão de Alberto de Oliveira ao parnasianismo, Meredionais de 1884, inquestionável marco do parnasianismo brasileiro. Conquanto o tema não seja novo, o tratamento dado à seqüência de três sonetos já é decididamente parnasiana: à poesia plástica do soneto de abertura, sucede a descrição idealizante do segundo

Cabelo errante e louro, a pedraria

Do olhar faiscando, o mármore luzindo

Alvirróseo do peito , - nua e fria,

Ela é a filha do mar, que vem sorrindo.

\section{[ ] Vede-a veio do abismo!}

e se fecha com um soneto em que se reitera o desaparecimento da mulher perfeita e imaculada:

Mas quando o corpo escultural, perfeito,

Molhas na vaga e a coma te flutua

Como em doudo pulsar me estala o peito!

Tremo de zelos e o meu ser recua,

Vendo-te, e vendo o mar que vem desfeito

Lavar-te em beijos, Afrodite nua.

O ideal marmóreo, ainda que referido à antiguidade clássica, é já contribuição parnasiana. Talvez, possa-se procurar a sua origem nos versos programáticos do metapoema "L'art" com que Théophile Gautier, o precursor do movimento da "arte pela arte”, abriu a segunda edição de Émaux et camées de 1859.
Oui, l'oeuvre sort plus belle

D'une forme au travail

Rebelle,

Vers, marbre, onyx, émail.

$[\ldots]$

Statuaire, repousse

L'argile que pétrit

Le pouce,

Quand flotte ailleurs l'esprit;

Lutte avec le carrare,

Avec le paros dur

Et rare,

Guardiens du contour pur;

$[\ldots]$

Tout passe. L'art robuste

Seul a l'éternité;

Deve-se, contudo, ressaltar a diferença entre o que preconiza o célebre poema de Théophile Gautier, de um lado, a opção pela matéria dura, difícil e nobre que exige a destreza, a atenção, a dedicação total do artista à obra e a meticulosidade no trabalho; e, de outro lado, o alargamento ou ampliação deste significado originalmente visado para um campo semântico mais amplo que passa, entre os parnasianos brasileiros, a incorporar também a figura feminina perfeita, além da artesania do poema. Ambos, porém, comungam o princípio de que só a arte é eterna. No parnaso brasileiro, o ideal marmóreo materializa-se costumeiramente em estátua de rara perfeição que evoca, revive, talvez ecoe, a beleza de um outro plano, mítico, divino, transcendental. $\mathrm{O}$ "ideal da pedra clara", como magistralmente o definiu Teófilo Dias, em "A estátua", funde a beleza da matéria - o mármore e o volume , à forma "escultural", no sentido de modelar, perfeita. É como se um sonho se materializasse.

Fosse-me dado, em mármor de Carrara, Num arranco de gênio e de ardimento, Às linhas do teu corpo o movimento Suprimindo, fixar-te a forma rara,

Cheio de força, vida e sentimento, Surgira-me o ideal da pedra clara, E em fundo, eterno arroubo, se prostrara, Ante a estátua imortal, meu pensamento.

Do albor de brandas formas eu vestira Teus contornos gentis; eu te cobrira Com marmóreo cendal os moles flancos,

E a sôfrega avidez dos meus desejos Em mudo turbilhão de imóveis beijos As curvas te enrolara em flocos brancos.

Para eternizar a beleza deslumbrante, porém efêmera, a mulher deve trocar a existência corpórea pela simbólica, tornando-se obra de arte, "mais forte que os metais", como preconizava Théophile Gautier no referido metapoema "L'art" : "Les dieux eux-mêmes meurent / Mais les vers souverains / Demeurent / Plus fort que les airains.” . Daí a mutação por 
que passa a mulher no texto acima referido de Teófilo Dias, "A estátua": a mulher vai perdendo a vida (os movimentos) para, materializando-se no mármore, tornar-se imortal. É curioso observar neste poema o contraste entre o desejo do poeta, ardente e em ação, e a imobilidade e frieza da mulher tornada estátua. Aqui o ímpeto erótico do poeta não é meramente afastado ou diferido, ele é o agente da metamorfose que se conclui com a petrificação da mulher. Em "Esfinge" Teófilo Dias retoma um símbolo do imaginário ocidental oriundo da antiguidade greco-latina: o ser híbrido, meio humano, meio animal, sobrenatural de qualquer forma, ostentava a face feminina à entrada da Tebas mítica do tempo de Édipo, enquanto propunha enigmas indecifráveis, que, se não desvelados, resultavam na morte do incauto passante. É enquanto imagem da mulher perigosa e enigmática que a esfinge interessa a Teófilo Dias, pois é assim que seu caráter contraditório se manifesta e fascina o poeta.

Tuas pupilas alaga

Não sei que acerba ternura,

Cuja luz cruel me afaga,

Cujo afago me tortura.

Unge-te o seio moreno

Um perfume sufocante,

Suave como um calmante,

Pérfido como um veneno.

Freme-te a alma fatal

No frágil corpo nervoso,

Como um filtro perigoso

Numa prisão de cristal.

Ora, a esfinge é também uma estátua, ela funde o enigma da atração irresistível e letal com a imagem petrificada, isto é, eternizada da mulher, inacessível, portanto; embora aqui não nobilitada pelo mármore.

E eu te amo, beleza fátua,

Minha perpétua loucura,

Como o verme a flor mais pura,

E o musgo a mais bela estátua!

O tema da esfinge é retomado por Bilac no segundo soneto de uma seqüência de três denominada "Édipo" em Tarde, livro publicado postumamente em 1919. O soneto se chama "A Esfinge" e parte de uma epígrafe de Sófocles. Os quartetos insistem sobre as contradições da mulher fatal, deusa e monstro, enquanto os tercetos focalização a vitória de Édipo e a destruição da esfinge. Os dois últimos versos parecem acenar para uma visão mais humana da esfinge, antes mulher, ser humano, que qualquer outra coisa.

Perto de Tebas, junto a um monte, sobre o Ismeno, Águia e mulher, serpente e abutre, deusa e harpia, Tapando a estrada, à espera, - aterrava e sorria O monstro sedutor, horrível e sereno:

"Devoro-te, ou decifra!" Era fascínio o aceno; A voz, morna e sensual, tinha afeto e ironia, Graça e repulsa; e a luz dos olhos escorria Fluido filtro, estilando um pérfido veneno.
Mas Édipo desvenda o enigma . . . Ruge em fúria O Grifo, e escarva o chão, bate contra o rochedo, Rola em vascas, em sangue ardente a areia tinge,

E fita o campeador no uivar da extrema injúria . . . E o Herói recua, vendo, entre esperança e medo,

Rancor e compaixão no verde olhar da Esfinge.

A transformação da mulher em estátua, enquanto estratégia para simultaneamente eternizá-la e torná-la inacessível ao desejo cru, carnal, é análogo à visão da mulher ideal que surge em sonho. O parnasianismo não operava aqui meramente com a interdição do desejo imposta pela sociedade patriarcal, típica da primeira metade do século e que condicionou o discurso idealizante romântico. A figura venusiana, que desaparece no mar envolta em ondas e cercada de criaturas mitológicas marinhas, a estátua de mármore tão bela quanto fria e a aparição em sonho, todas, intocadas e inacessíveis, remetem ao ideal de perfeição formal que obsedou os parnasianos. As mais próximas da matéria eram a estátua e a figura venusiana: pela matéria pesada, densa e nobre na primeira, pelos dotes e atrativos físicos exacerbados na segunda. Da mesma forma que a visão da mulher perfeita entrevista em sonho é fruto do trabalho onírico, o poema é fruto do trabalho poético, e ambos constituem metáforas do desejo do poeta. Esta visão de mulher surge em poemas como "Sonho" e "Acordando" de Alberto de Oliveira; o primeiro de Versos e Rimas de 1895, e o segundo de Livro de Ema, publicado na segunda série de Poesias em 1912. Dos dois é o segundo que mais nos interessa no momento.

Quero-te, vem! se acaso da neblina

Do sonho as formas desatar te é dado,

Se não és sonho tu, se ora acordado,

Posso tocar-te, sombra peregrina!

Com o mesmo rosto pálido e magoado, Triste o sorriso à boca purpurina, Com o todo, enfim, da aparição divina, Rompe da névoa, meigo vulto amado!

Encarna-te! aparece! exsurge! acode!

E em minha fronte a coma ondeante e escura,

Cheia de orvalhos, úmida, sacode;

Mas se te dói pisar este medonho

Chão de abrolhos que eu piso, imagem pura,

Torna outra vez a aparecer-me em sonho.

É inequívoco o acento espiritualizante do texto: "sombra peregrina", "aparição divina", "vulto amado" e "imagem pura", são os termos empregados para referir-se à figura feminina desmaterializada, a quem o eu lírico se dirige, não em diálogo, que a nivelaria, mas num monólogo que sabe à prece. É no sonho que ela se encontra entronizada; não tanto para ser amada - pelo menos não de um amor mundano, humano - , antes para ser admirada, quiçá venerada. $\mathrm{O}$ imperativo que abre o poema e aqueles que se encontram no primeiro verso do primeiro terceto, os quais parecem decidir o poema pela saída da mulher do plano fantasioso e ideal do sonho para sua materialização no mundo do eu lírico e realização do desejo, cedem à oposição imaginária da mulher em pisar o "medonho chão de abrolhos que eu piso". Ela permanece, portanto, no plano imaginário, no plano da fantasia, do sonho; amada, desejada, invocada, porém, imaterial, ideal; "imagem 
pura", forma pura colimada, ansiada pelos adeptos da arte pela arte.

Foi essa ânsia que precisou encontrar expressão mais plena e direta e a logrou na figura híbrida, humana e mítica nisso se assemelhando à esfinge - da sereia. Foi a sereia, por se colocar mais próxima e, portanto, pelo menos teoricamente, em um plano mais à medida do homem, diferente da figura venusiana, da estátua marmórea e da "aparição divina" no sonho, que permitiu ao parnasianismo enunciar a angústia relacionada à procura sisífica da perfeição. A sereia será talvez a imagem poética que melhor represente e a mulher perfeita e o ideal da perfeição formal, pois ela acena para o infinito do desejo que move o homem. O homem tem na natureza duas coisas que apontam para o infinito: o céu e o mar. A sereia nada no mar e voa no céu; mas ela vem à superfície do mar e não sobe aos céu, ela permanece entre os dois infinitos no horizonte humano, para lembrar ao homem do chamado do infinito, que é o chamado da poesia e da transcendência.

Foi seguindo os conselhos de Circe que Odisseu conseguiu o que ninguém até então havia logrado: sobreviver ao canto das sereias. Odisseu não era um mortal qualquer e mesmo assim precisou ser amarrado ao mastro para resistir ao chamado avassalador do canto fatal. $O$ texto homérico fecundou $o$ imaginário da literatura ocidental, não apenas com a figura das sereias, cujo canto enfeitiçante atraía os homens para o abismo, mas com um cem número de personagens e episódios históricos, míticos ou fantásticos, e por isso foi uma das principais fontes - ao lado dos poetas trágicos - das referências do classicismo da antiguidade latina e renascentista, do neoclassicismo e dos parnasianos à antiguidade grega. Reportamo-nos a uma era em que o canto mavioso da sereia ainda guardava toda a sua excelsa beleza, seu poder incomparável de sedução encantava, fascinava e matava. Anterior a era em que nos encontramos, caracterizada por Adorno como a era do desencanto. Para compreender o que os parnasianos visavam quando tratavam das representações da mulher fatal - a Vênus, a estátua, a esfinge, a mulher do sonho e a sereia, dentre outras figurações - , é preciso esforçarmo-nos por retornar à visão de mundo poética onde estes seres habitavam e preservavam intensamente seus poderes. Os momentos mais representativos da presença da sereia no parnaso brasileiro encontram-se nos poemas "Coerulei oculi" de Raimundo Correia e "Medalha Antiga" e "A Iara", os dois últimos de Olavo Bilac.

"Coerulei oculi" de Raimundo Correia e "Medalha Antiga" de Olavo Bilac são textos que partem de modelos franceses, o primeiro de Théophile Gautier e o segundo de Leconte de Lisle. Em "Medalha Antiga" temos poesia plástica, na qual a descrição da medalha vem fecundada pelo imaginário mitológico, mas o poeta restringe-se a destacar a extrema beleza da personagem retratada.

Nua a deusa, nadando, a onda dos seios túmidos Leva diante de si, amorosa e sensual:

E a onda mansa do mar borda de argênteos flóculos Seu pescoço imortal.

Livre das fitas, solto em quedas de ouro, espalha-se Gotejante o cabelo: e o seu corpo encantado Brilha nas águas, como, entre violetas unidas, Um lírio imaculado.

Não se flagra aqui a volúpia ansiosa que se manifesta em "Coerulei oculi", texto que ao lado de "Plenilúnio" e "Anoitecer" formam um nicho simbolista na obra do grande mestre do parnaso brasileiro. Neste poema de Raimundo Correia encontramos expressos, em versos de musicalidade e ritmo impares, de uma sonoridade toda aveludada, quase em surdina, a realização do encontro e da união onírica com a mulher perfeita e fatal, em cujos braços encontra o eu lírico amor, morte e a perfeição sonhada. Ao contrário dos outros poemas relativos às demais representações da mulher fatal - onde invariavelmente é o eu lírico que monologa, suplica ou meramente descreve a "aparição divina" -, aqui não apenas ela está presente, mas fala e é ela que chama por ele, que o convida a acompanhá-la ao abismo do desejo e da morte.

Mago prestígio me enleia

E ao fundo abismo de luz

Me arrasta, como a sereia

Que a Harald Harfagar seduz;

Me arrasta à ignota voragem, Até que eu nela me arroje, Trás da impalpável imagem, Que, aérea e fátua, me foge ...

N'água esconde a ninfa bela

A cauda argêntea; e o brancor

Da espádua lisa revela,

Corando, da espuma à flor... .

Incha e, como um seio, arqueja

A vaga; em mórbido acento,

Na cava concha solfeja,

Soluça, ressona o vento ...

"Vem, reclina-te em meu leito

De âmbar, e o saibo de fel

Das ondas verás, desfeito,

Manar-te da boca, em mel;

"O pélago estoira e zune

Por cima; e a paz aqui mora,

Sem que o rumor a importune

Das tempestades de fora...

"Vem! Sem tédio, nem bocejos,

$\mathrm{O}$ esquecimento imortal

Bebamos juntos, dos beijos

Pelo copo de coral!"

Assim é que a voz me fala,

Desse olhar que me extasia;

E ao fundo d'água, a escutá-la,

Desço ... E o himeneu principia ...

"A Iara" de Bilac não parte de nenhum modelo estrangeiro, parte do imaginário nacional indígena. Ela é a nossa mãe d'água, de beleza e canto irresistíveis, que surge ao cair da tarde à beira de lagos e rios e põe-se a cantar. Seus olhos verdes translúcidos, os cabelos de reflexos dourados e o canto melodioso arrastam o homem para o fundo das águas. Bilac preferiu preservar a sua aura mítica e a manteve imaculada, impoluta, casta diva, eternamente seduzindo e encantando, como a imorredoura magia dos versos. Aqui não há encontro, não há enlace como no "Coerulei oculi" de Raimundo Correia, a "linda mulher, esquiva e rara" preserva todo o seu mistério, todo o seu fascínio, como a poesia deveria preservar, sobretudo em nossa pobre era desencantada, 
nesse triste mundo que, para lembrar o mestre do simbolismo brasileiro, esse "mundo que não sonha". O poema se encerra com uma chave-de-ouro, com que só Bilac saberia nos brindar: não só o verso formalmente perfeito e rico de efeito, mas sobretudo a idéia do velamento do enigma da mulher e da poesia que se mantém. Bilac age coerentemente com a idéia da religião da arte e opta por não desvelar o mistério, que continua então vivo. É um convite à poesia, ao que há de mágico, encantatório, mítico, transcendente na poesia. É poesia pura, aurida na seiva do imaginário nacional indígena. Poesia parnasiana entranhada, não só, mas também na cultura brasileira, ao contrário do que afirma uma certa crítica que ainda hoje pretende insistir sobre o alheamento em que floresceu o parnasianismo brasileiro.

Vive dentro de mim, como num rio,

Uma linda mulher, esquiva e rara,

Num borbulhar de argênteos flocos, Iara

De cabeleira de ouro e corpo frio.

Entre as ninféias a namoro e espio:

E ela, do espelho móbil da onda clara,

Com os verdes olhos úmidos me encara,

E oferece-me o seio alvo e macio.

Precipito-me, no ímpeto de esposo,

Na desesperação da glória suma,

Para a estreitar, louco de orgulho e gozo...

Mas nos meus braços a ilusão se esfuma:

E a mãe-d'água, exalando um ai piedoso,

Desfaz-se em mortas pérolas de espuma.

Se fossem de todo alheios à nossa cultura, os temas parnasianos e simbolistas não retornariam mais, emparedados nos muros do esquecimento coletivo. Não é nessa direção que aponta manifestações próximas e recentes da cultura popular. O desfile de 2009 da escola de samba Império Serrano retomou o tema, consagrado no carnaval de 1976, "A lenda das sereias e os mistérios do mar", no qual é homenageada a sereia afro-brasileira, Iemanjá. Quem sabe se não era a ela também que cantava mestre Candeia, em um de seus maiores sucessos " $\mathrm{O}$ Mar Serenou”, indelevelmente interpretado por Clara Nunes.

O mar serenou quando ela pisou na areia

Quem samba na beira do mar é sereia

Creio tratar-se de testemunhos suficientemente eloqüentes e insuspeitos, para convidar a crítica e a historiografia literárias brasileiras a uma revisão do modo como tradicionalmente parnasianismo e simbolismo foram até aqui avaliados: como se tivessem sido e continuassem desvinculados da cultura e da realidade brasileiras e desprovidos de mérito e valor intrínsecos. Se estes vínculos não estavam presentes ou em destaque na primeira hora, ou em certos aspectos ou autores, apareceram oportunamente, como no soneto de Bilac, ou foram tecidos pelos leitores que vieram depois e redescobriram, nas matrizes parnasianas do nosso imaginário poético, as imagens imorredouras para falar da beleza e do mistério da mulher e da poesia. Creio, sobretudo, tratar-se de testemunhos de que vale a pena reler a poesia parnasiana e simbolista com outros olhos, pelos seus próprios méritos e valor, enquanto realização poética do mais alto nível, tentando, tanto quanto possível, aproximar-se de uma leitura mais isenta e desvencilhar-se dos lugares comuns da crítica e da historiografia literárias, a fim de não perpetuar equívocos e vícios interpretativos que há muito deveriam ter sido reparados.

\section{Referências bibliográficas}

ASSIS, Machado de. "A nova geração". In Obras Completas, volume 29: Crítica Literária. São Paulo, Editora Mérito, 1962.

BILAC, Olavo. Obra reunida. Rio de Janeiro: Nova Aguilar, 1996.

BOSI, Alfredo. História concisa da Literatura Brasileira. $41^{\mathrm{a}}$. ed. São Paulo: Cultrix, 2003.

CANDIDO, Antonio. “Os primeiros baudelairianos.” In A educação pela noite e outros ensaios. $3^{\mathrm{a}}$. ed. São Paulo, Ática, 2000.

CORREIA, Raimundo. Poesias. (Seleção do autor). Rio de Janeiro: Nova Aguilar; Brasília: INL, 1976.

GADAMER, Hans-Georg. Verdade e Método, I. Traços fundamentais de uma hermenéutica filosófica. Tradução de Flávio Paulo Meurer. $2^{\mathrm{a}}$. ed. Petrópolis, Vozes, 1998.

Verdade e Método, II. Complementos e índice. Tradução de Ênio Paulo Giachini. Petrópolis, Vozes, 2002.

JAUSS, Hans Robert. A história da literatura como provocação à teoria literária. Tradução de Sérgio Tellaroli. São Paulo, Ática, 1994. Pour une esthétique de la réception. Tradução de Claude Maillard e prefácio de Jean Starobinski. Paris, Gallimard (Tel), 1990. Pour une herméneutique littéraire (Ästhetische Erfahrung und literarische Hermeneutik, 1982). Tradução de Maurice Jacob, Paris, Gallimard, 1988.

MOISÉS, Massaud. História da Literatura Brasileira, volume II: Realismo e Simbolismo. 5a. ed. São Paulo: Cultrix, 2004.

OLIVEIRA, Alberto de. Melhores poemas. Seleção de Sânzio de Azevedo. São Paulo: Global; Rio de Janeiro: Academia Brasileira de Letras, 2007.

PACHECO, João. A Literatura Brasileira, volume III: O realismo (1870-1900). São Paulo: Cultrix, 1971.

RAMOS, Péricles Eugênio da Silva. "A renovação parnasiana na poesia”. In COUTINHO, Afrânio (dir.). A Literatura no Brasil, volume III: Realismo-Naturalismo-Parnasianismo. Rio de Janeiro, Editorial Sul Americana, 1969.

SANT'ANNA, Affonso Romano de. "Da mulher esfinge como estátua devoradora ao strip-tease na alcova." In O canibalismo amoroso. $2^{\mathrm{a}}$. ed. São Paulo, Brasiliense, 1985. 